\title{
EXPERIMENTAL VERIFICATION OF THE SCALING LAWS FOR CFB BOILERS OF DIFFERENT DESIGNS
}

\author{
Paweł Mirek $^{* 1}$, Marcin Klajny ${ }^{2}$ \\ ${ }^{1}$ Częstochowa University of Technology, Faculty of Infrastructure and Environment, Institute of \\ Advanced Energy Technologies, ul. Dąbrowskiego 69, 42-201 Częstochowa, Poland
}

${ }^{2}$ AMEC Foster Wheeler, Foster Wheeler Energia Polska Sp. z o.o., ul. Staszica 31, 41-200

Sosnowiec, Poland

\begin{abstract}
In the paper flow dynamic similarity criteria have been presented to reflect the macroscopic flow pattern in the combustion chamber of large-scale circulating fluidised bed boilers. The proposed scaling rules have been verified on two cold models of CFB boilers operating in Tauron Wytwarzanie S.A. - El. Lagisza division (scale factor 1/20) and Fortum Power and Heat Poland Sp. z o. o. Czestochowa division (scale factor 1/10) - working with the power of $966 \mathrm{MW}_{\text {th }}$ and $120 \mathrm{MW}_{\text {th }}$, respectively. As follows from the results of measurements, regardless of CFB boiler's geometry the use of a defined set of criterial numbers allows to obtain satisfactory agreement between the suspension density distributions registered in the CFB boilers and scaling models.
\end{abstract}

Keywords: fluidisation, circulating fluidised bed, similarity, scaling, hydrodynamics

\section{INTRODUCTION}

For over four decades, an increasing pace of development in the Circulating Fluidised Bed (CFB) fuel combustion technology has been observed. In its classic form, owing to experience gained from hundreds of operating facilities, this technology has already attained its maturity in many respects. However, new challenges for a greater operational flexibility of power units and the quality of delivered fuels, as well as for the method of organisation of the combustion process itself, force boiler designers to solve ever new problems, in which laboratory tests and mathematical modelling play an essential role.

The use of numerical algorithms in modelling of phenomena typical for CFB boilers is possible in the semi-empirical and the classic approaches. In the classic approach (Computational Fluid Dynamics CFD), one can choose between Euler-Lagrange or two-fluid Euler-Euler models. In the case of the Euler-Lagrange type models, special consideration should be given to Multiphase-Particles in Cell (MP-PIC) models and classic CFD models coupled with a discrete element method, which enable simulations of fluidised-bed systems on a commercial scale (Werther and Hartge, 2014). Unfortunately, the use of available algorithms in combination with the high performance of existing computational clusters does not ensure fast and sufficiently accurate computation results to be obtained. This, in particular, applies to the lower part of the combustion chamber, where it is especially difficult to represent the turbulent flow of a two-phase mixture accompanied by chemical reactions. In this situation, a solution is sought by reducing the mathematical expressions describing the process to a dimensionless form in order to formulate the dimensionless criterial numbers that contain decision- 
making parameters important from the scaling point of view. The sets of those parameters enable one to define the theoretical grounds for transferring the process from the commercial scale to the laboratory scale, and vice versa, provided that the basic requirement of dynamic flow similarity theory, which is to preserve the geometrical similarity between the model and the boiler prototype, is satisfied. The basic theory on scaling of the flow phenomena in Circulating Fluidised Bed boilers one can find in the studies by Glicksman (2003), Horio (1997), Mirek (2011) or Van der Meer (1999).

Most criterial numbers defining the hydrodynamic similarity under circulating fluidised bed conditions have been formulated based on differential equations proposed by Anderson and Jackson (Anderson and Jackson, 1967). A summary of selected dimensionless scaling parameters is given in Table 1.

Table 1. Typical sets of dimensionless scaling parameters

\begin{tabular}{|c|c|c|c|}
\hline Dimensionless scaling parameters & Conditions & Comment & Author(s) \\
\hline $\begin{array}{l}\frac{U_{0}^{2}}{g L}, \frac{\rho_{p}}{\rho_{f}}, \frac{U_{0} d_{p} \rho_{p}}{\mu}, \frac{U_{0} L \rho_{f}}{\mu}, \frac{\dot{G}_{S}}{\rho_{p} U_{0}} \\
\varphi, P S D, \text { geometry }\end{array}$ & & Full set ${ }^{1}$ & $\begin{array}{l}\text { Glicksman et al. } \\
\text { (1990), Chang and } \\
\text { Louge (1992) }\end{array}$ \\
\hline$\frac{U_{0}^{2}}{g D_{h}}, \frac{\rho_{p}}{\rho_{f}}, \frac{d_{p}}{D_{h}}, \frac{\dot{G}_{S}}{\rho_{p} U_{0}}$, geometry & $\begin{array}{c}\text { Inertial regime } \\
R e_{d}>1000\end{array}$ & \multirow{3}{*}{$\begin{array}{c}\text { Four } \\
\underset{\text { dimensionless }_{\text {groups }}^{2}}{ }\end{array}$} & $\begin{array}{c}\text { Van der Meer et } \\
\text { al. (1999) }\end{array}$ \\
\hline$\frac{U_{0}^{2}}{g D_{h}}, \frac{\rho_{p}}{\rho_{f}}, \frac{U_{0}}{u_{m f}}, \frac{\dot{G}_{S}}{\rho_{p} U_{0}}$, geometry & $\begin{array}{l}\text { High } R e_{d} \text { and low } \\
\text { slip velocities at } \\
\text { any } R e_{d}\end{array}$ & & $\begin{array}{c}\text { Glicksman et al. } \\
\text { (1993) }\end{array}$ \\
\hline$\frac{U_{0}^{2}}{g D_{h}}, \frac{\rho_{p}}{\rho_{f}}, \frac{U_{0}}{u_{t}}, \frac{\dot{G}_{S}}{\rho_{p} U_{0}}$, geometry & & & Horio et al. (1989) \\
\hline$\frac{U_{0}^{2}}{g D_{h}}, \frac{U_{0}}{u_{m f}}, \frac{\dot{G}_{S}}{\rho_{p} U_{0}}$, geometry & $\begin{array}{c}\text { Viscous regime } \\
R e_{d}<4\end{array}$ & \multirow{2}{*}{$\begin{array}{c}\text { Simplified set }{ }^{2} \\
\text { Three } \\
\text { dimensionless } \\
\text { groups }\end{array}$} & $\begin{array}{c}\text { Glicksman et al. } \\
\text { (1993) }\end{array}$ \\
\hline$\frac{U_{0}^{2}}{g D_{h}}, \frac{U_{0}}{u_{t}}, \frac{\dot{G}_{S}}{\rho_{p} U_{0}}$, geometry & $\begin{array}{l}\text { Viscous regime } \\
\qquad \operatorname{Re}_{d}<4 \\
5<R e_{d}<15\end{array}$ & & Horio et al. (1989) \\
\hline
\end{tabular}

${ }^{1)}$ particle/particle and particle/wall coefficients of restitution and friction, electrostatic forces and cohesion have been neglected

2) particle shape, size distribution, particle/particle and particle/wall coefficients of restitution and friction, electrostatic forces and cohesion have been neglected

As can be seen from Table 1, the state of the full hydrodynamic similarity can be described with a set of five criterial numbers containing eight parameters: $U_{0}, \mathrm{~g}, \mathrm{~L}, \rho_{p}, \rho_{f}, d_{p}, \mu$ and $\dot{G}_{s}$. Among them, only two may be assumed at an arbitrary level: $\mu$ and $\rho_{f}$. In an atmospheric fluidised-bed boiler, preserving the full dynamic flow similarity in relation to the laboratory model poses additional difficulties associated, e.g., with the need for building a test-stand of a size of $0.225 D_{p}$ and using loose material of a density equal to $3.82 \rho_{p b}$ (Glicksman et al., 1993). Therefore, when it is only aimed at representing the macroscopic flow pattern and at checking whether or not the conditions in the combustion chamber satisfy the inequality $R e_{d} \leq 15$ (Glicksman et al., 1987), the set of scaling parameters can be reduced to the following form 


$$
\frac{U_{0}^{2}}{g L}, \frac{U_{0}}{u_{m f}}, \frac{\dot{G}_{S}}{\rho_{p} U_{0}}, \varphi, P S D, \text { geometry }
$$

The scaling formulae (1) reduces the number of dependent parameters from five to three, thus allowing a free choice of both the stand scale and the loose material density, while retaining the fluidisation regime, the macroscopic particle motion and the suspension density distribution along the combustion chamber height (Grace et al., 1996; Mirek, 2011). In practice, the existence of two independent parameters imposes the necessity of performing a series of experimental tests with the aim of establishing their optimal values. For this reason, the use of the simplified scaling relationships (1) should be preceded by a detailed analysis of the influence of both loose material density and the stand scale on the degree of fitting of the basic hydrodynamic parameters.

The problem of the effect of loose material density on the degree of fitting of the vertical pressure distributions in the CFB boiler combustion chamber to the experimental data was the subject of tests carried out in a transparent ( $1 / 6$ scale) model of the $12 \mathrm{MW}$ boiler operating at Chalmers University of Technology (Kolar and Leckner, 2006). As shown by performed measurements, using a higher density material (bronze: $\rho_{p}=8563 \mathrm{~kg} / \mathrm{m}^{3}, d_{32}=73.4 \mu \mathrm{m}, 69.5 \mu \mathrm{m}$ ) allows for a better fitting of the static pressure curves to be obtained, compared to the lower density material (quartz sand: $\rho_{p}=2368 \mathrm{~kg} / \mathrm{m}^{3}$, $\left.d_{32}=125 \mu \mathrm{m}\right)$.

The problem of the cold model scale effect on the degree of representation of basic hydrodynamic parameters was the subject of investigations described in the studies by Glicksman et al. (1993) or Mirek et al. (2014). As follows from the study carried out by Mirek et al. (2014), for the cold models using scales of $1 / 10$ and $1 / 20$, a better degree of fitting of the loose material suspension density distributions, compared to the distributions recorded in the boiler combustion chamber, can be obtained in a larger-scale model. A similar conclusion was drawn by Glicksman et al. (1993), who performed scaling experiments with $1 / 4$ and $1 / 16$-scale cold models.

To sum up, even though the use of the simplified flow similarity formulae allows a selection of an arbitrary cold model scale and loose material density, investigations into the possibility of their use for different CFB boiler designs are hardly documented in the literature. This paper reports the results of the experimental verification of the simplified relationships scaling the hydrodynamics of $966 \mathrm{MW}_{\text {th }}$ and $120 \mathrm{MW}_{\text {th }}$ CFB boilers of different geometries, operating, respectively, at Tauron Wytwarzanie S.A. - the Lagisza Power Plant Division, and at Fortum Power and Heat Polska Sp. z o. o. - the Czestochowa Division.

\section{FORMULATION OF THE SIMPLIFIED SCALING LAWS}

Obtaining the macroscopic flow pattern occurring in the CFB boiler combustion chamber using a cold model is possible on the assumption of the geometric similarity, the loose material particle size distribution similarity and the equality of at least three criterial numbers defined by Eq. (1). As the measurement of the external solid circulation flux $\dot{G}_{S}$ in a real boiler is very difficult to accomplish, scaling formulae (1) can be alternatively substituted with criterial numbers of the following form (Mirek, 2011)

$$
\frac{U_{0} d_{p} \rho_{f}}{\mu}, \frac{U_{0}}{u_{t}}, \frac{d_{p}^{3} \rho_{f}\left(\rho_{p}-\rho_{f}\right) g}{\mu^{2}}, P S D, \text { geometry }
$$

Criterial numbers in Eq. (2), along with the basic CFB hydrodynamics equations, enable the determination of:

- particle mean diameter in the cold model 


$$
d_{p m}=\left[d_{p b} \frac{\mu_{m}^{2}}{\mu_{b}^{2}} \frac{\rho_{f b}}{\rho_{f m}} \cdot \frac{\left(\rho_{p b}-\rho_{f b}\right)}{\left(\rho_{p m}-\rho_{f b}\right)}\right]^{1 / 3}
$$

- minimum fluidisation velocity

$$
u_{m f}=\frac{A r}{d_{p}} \frac{\mu}{\rho_{f}} \frac{\varepsilon^{3} \varphi^{2}}{150(1-\varepsilon)}
$$

- terminal velocity of particles

$$
u_{t}=\sqrt{\frac{4}{3} \frac{A r^{1 / 3}}{C_{d}}}\left[\frac{\mu g\left(\rho_{p}-\rho_{f}\right)}{\rho_{f}^{2}}\right]^{1 / 3}
$$

- drag coefficient

$$
C_{d}=\frac{432}{d_{*}^{3}}\left(1+0.022 d_{*}^{3}\right)^{0.54}+0.47\left(1-e^{-0.15 d_{*}^{0.45}}\right)
$$

Table 2 summarises the most important operation parameters of the investigated boilers and their

\begin{tabular}{|c|c|c|c|c|c|c|c|c|c|}
\hline \multirow[b]{3}{*}{ MCR } & \multirow[b]{3}{*}{$\%$} & \multirow{2}{*}{\multicolumn{2}{|c|}{$\begin{array}{l}\text { Lagisza } 966 \mathrm{MW}_{\text {th }} \\
\text { CFB boiler }\end{array}$}} & \multirow{2}{*}{\multicolumn{2}{|c|}{$\begin{array}{c}\begin{array}{c}\text { Lagisza cold } \\
\text { model }\end{array} \\
\text { Scale } 1 / 20\end{array}$}} & \multirow{2}{*}{\multicolumn{2}{|c|}{$\begin{array}{l}\text { Fortum } 120 \mathrm{MW}_{\text {th }} \\
\text { CFB boiler }\end{array}$}} & \multirow{2}{*}{\multicolumn{2}{|c|}{$\begin{array}{c}\text { Fortum cold model } \\
\text { Scale } 1 / 10\end{array}$}} \\
\hline & & & & & & & & & \\
\hline & & 100 & 40 & 100 & 40 & 100 & 40 & 100 & 40 \\
\hline$U_{\mathrm{o}}$ & $\mathrm{m} / \mathrm{s}$ & 5.10 & 2.62 & 1.49 & 0.76 & 5.02 & 3.28 & 1.47 & 0.96 \\
\hline $\mathrm{PA} / \mathrm{SA}$ & - & 1.86 & 5.25 & 1.86 & 5.25 & 1.50 & 5.25 & 1.50 & 5.25 \\
\hline$d_{32}$ & $\mu \mathrm{m}$ & \multicolumn{2}{|c|}{122.99} & \multicolumn{2}{|c|}{44.05} & \multicolumn{2}{|c|}{208.41} & \multicolumn{2}{|c|}{74.43} \\
\hline$d_{50}$ & $\mu \mathrm{m}$ & \multicolumn{2}{|c|}{234.57} & \multicolumn{2}{|c|}{84.01} & \multicolumn{2}{|c|}{180.02} & \multicolumn{2}{|c|}{63.73} \\
\hline$\rho_{\mathrm{p}} / \rho_{\mathrm{f}}$ & $\mathrm{kg} / \mathrm{m}^{3}$ & \multicolumn{2}{|c|}{8724} & \multicolumn{2}{|c|}{2076} & \multicolumn{2}{|c|}{8724} & \multicolumn{2}{|c|}{2076} \\
\hline$\mu$ & $\mathrm{Pa} \mathrm{s}$ & \multicolumn{2}{|c|}{$4.456 \times 0^{-5}$} & \multicolumn{2}{|c|}{$1.813 \times 10^{-5}$} & \multicolumn{2}{|c|}{$4.456 \times 10^{-5}$} & \multicolumn{2}{|c|}{$1.813 \times 10^{-5}$} \\
\hline$T$ & $\mathrm{~K}$ & \multicolumn{2}{|c|}{1123} & \multicolumn{2}{|c|}{293} & \multicolumn{2}{|c|}{1123} & \multicolumn{2}{|c|}{293} \\
\hline$D$ & $\mathrm{~m}$ & \multicolumn{2}{|c|}{11.99} & \multirow{2}{*}{\multicolumn{2}{|c|}{$\begin{array}{c}0.6 \\
0139\end{array}$}} & \multirow{2}{*}{\multicolumn{2}{|c|}{$\begin{array}{c}7.72 \\
1194\end{array}$}} & \multicolumn{2}{|c|}{0.77} \\
\hline$u_{t}$ & $\mathrm{~m} / \mathrm{s}$ & \multicolumn{2}{|c|}{0.479} & & & 1.194 & & \multicolumn{2}{|c|}{0.355} \\
\hline$R e_{d}$ & - & 4.357 & 2.238 & 4.357 & 2.238 & 7.267 & 4.748 & 7.267 & 4.748 \\
\hline$A r$ & - & \multicolumn{2}{|c|}{7.68} & \multicolumn{2}{|c|}{7.68} & \multicolumn{2}{|c|}{37.4} & & \\
\hline$u_{m f}$ & $\mathrm{~m} / \mathrm{s}$ & 0.0 & & & & & & 0.0 & \\
\hline
\end{tabular}
corresponding cold model operation parameters.

Table 2. Parameters of the Lagisza $966 \mathrm{MW}_{\text {th }}$ and Fortum $120 \mathrm{MW}_{\text {th }} \mathrm{CFB}$ boilers and small-scale equivalents according to set of simplified scaling laws (2) and equations (3) - (6)

As can be seen from Table 2, both the $966 \mathrm{MW}_{\text {th }}$ Lagisza CFB boiler and the $120 \mathrm{MW}_{\text {th }}$ Fortum CFB boiler operate within the viscous flow limit, which allows both the same fluidisation regime and particle concentration profile to be preserved in the laboratory models.

\section{EXPERIMENTAL APPARATUS}

Experimental tests were carried out on the cold model stands of the $966 \mathrm{MW}_{\text {th }}$ and $120 \mathrm{MW}_{\text {th }} \mathrm{CFB}$ boilers operating, respectively, at Tauron Wytwarzanie S.A. - the Lagisza Power Plant Division, and at Fortum Power and Heat Polska Sp. z o. o. - the Czestochowa Division. The $966 \mathrm{MW}_{\text {th }}$ CFB boiler cold model was made using a scale of $1 / 20$, while the $120 \mathrm{MW}_{\text {th }}$ CFB boiler cold model, a scale of $1 / 10$. Cold models were built of plexiglass, while preserving the geometric similarity (Fig. 1). 

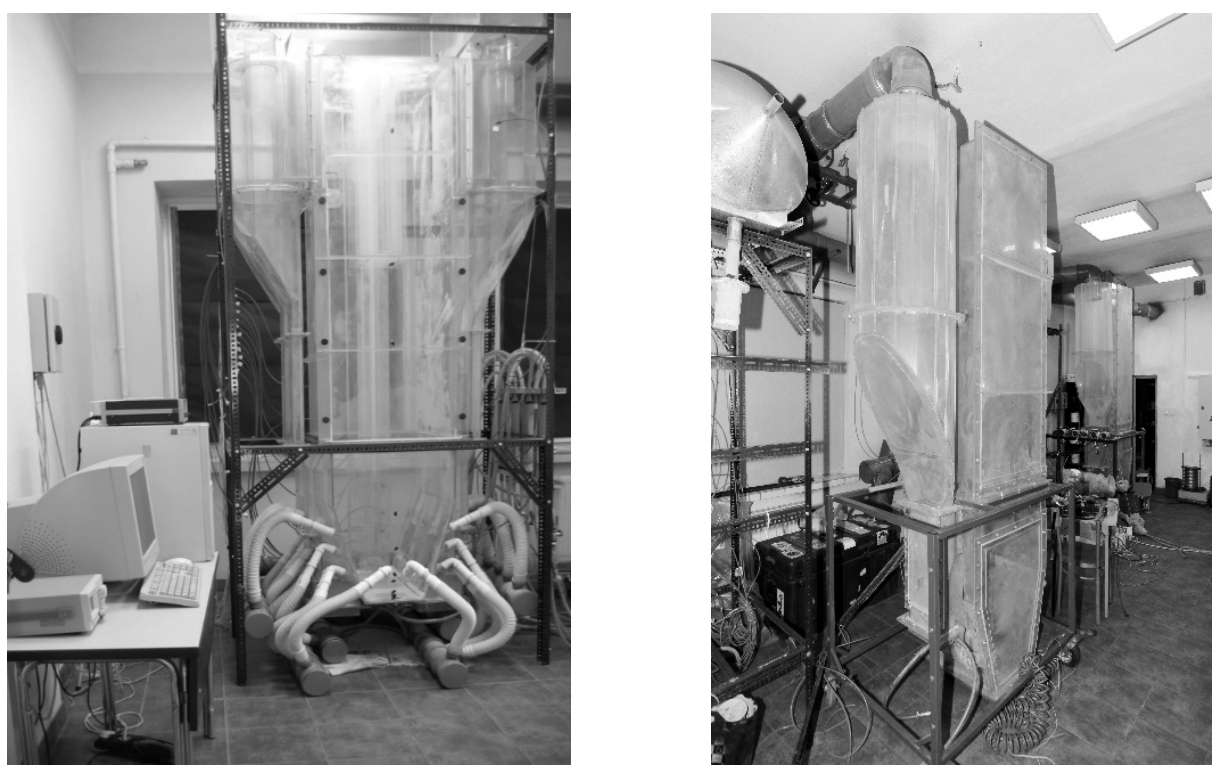

Fig. 1. Cold models of: a. Lagisza $966 \mathrm{MW}_{\text {th }} \mathrm{CFB}$ boiler - scale 1/20,

b. Fortum $120 \mathrm{MW}_{\text {th }} \mathrm{CFB}$ boiler - scale $1 / 10$
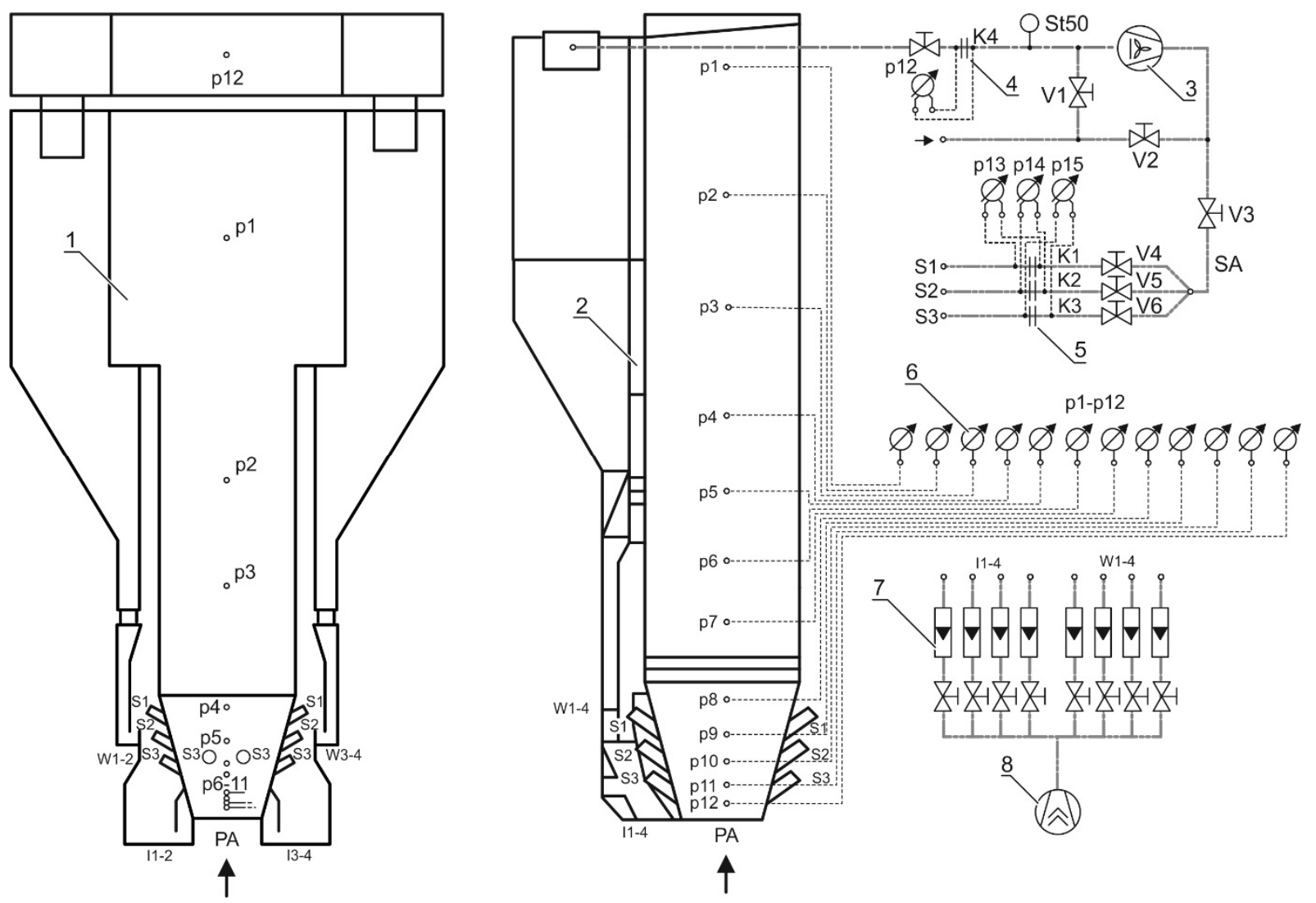

Fig. 2. Schematic diagrams of cold models: 1-Lagisza $966 \mathrm{MW}_{\text {th }} \mathrm{CFB}$ boiler - scale 1/20, 2-Fortum $120 \mathrm{MW}_{\text {th }}$ CFB boiler - scale 1/10, 3- industrial radial fan of $5500 \mathrm{~m}^{3} / \mathrm{h}, \Delta p=20 \mathrm{kPa}, 4$-measuring orifice plate for PA and SA, 5- measuring orifice plates for three SA streams (S1, S2, S3), 6-digital pressure sensors APR-2000ALW, 7-rotameters, 8-rotary screw compressor Aircenter $12 \mathrm{SFC} / 0.8 \mathrm{MPa}, 74 \mathrm{~m}^{3} / \mathrm{h}$.

Due to the symmetric construction of the Lagisza $966 \mathrm{MW}_{\text {th }}$ CFB boiler, its model represents half the length of the combustion chamber that is equipped with four cyclone separators and has a cross-section of $0.69 \times 0.53 \mathrm{~m}^{2}$. 
Figure 2 shows schematic diagrams of the experimental test-stands together with the primary (PA) and the secondary air (SA) supply systems. The test-stands were equipped with two independent compressed air systems, the first of which supplies the primary and the secondary air channels, while the other delivers air to Intrex separators, I1-I4, and to loop seals, W1-W4. The source of air for the first system is industrial fan, 3, with a maximum capacity of $5500 \mathrm{~m}^{3} / \mathrm{h}$ and a total pressure buildup of $20 \mathrm{kPa}$. For the second system, the air source is Aircenter 12SFC/0.8 MPa Roots blower, 8, with a capacity of $74 \mathrm{~m}^{3} / \mathrm{h}$.

The fluidising medium used in the tests was air of a density of $1.2 \mathrm{~kg} / \mathrm{m}^{3}$. The primary and secondary air fluxes could be controlled with flap valves, V1-V6. The volumetric flow rate of total air and secondary air was measured by the orifice plate measuring method using measuring orifice plates, K1K4. In addition, the primary air flux was measured using the ST50 thermal sensor. In static pressure measurements, APR-2000ALW intelligent differential pressure transducers, 5, with measuring ranges of \pm 2 and $\pm 10 \mathrm{kPa}$ were used. The streams of air delivered to the Intrex separators and the loop seals were measured with industrial rotameters, 7. During tests, pressures along the working chamber height were recorded at twelve measurement points, p1-p12, which for the $966 \mathrm{MW}_{\text {th }} \mathrm{CFB}$ boiler corresponded to the actual locations of the pressure measurement points.

- glass micro-particles $\left(\rho_{p}=2500 \mathrm{~kg} / \mathrm{m}^{3}\right)$ for the $966 \mathrm{MW}$ th $\mathrm{CFB}$ boiler, and

- quartz sand particles $\left(\rho_{p}=2500 \mathrm{~kg} / \mathrm{m}^{3}\right)$ for the $120 \mathrm{MW}_{\text {th }} \mathrm{CFB}$ boiler.

Figure 3 shows the particle size distributions of inert materials taken from the combustion chambers of the Lagisza $966 \mathrm{MW}_{\text {th }} \mathrm{CFB}$ boiler and the Fortum $120 \mathrm{MW}_{\text {th }} \mathrm{CFB}$ boiler, along with the scaled-down particle size distributions used for the cold model studies.
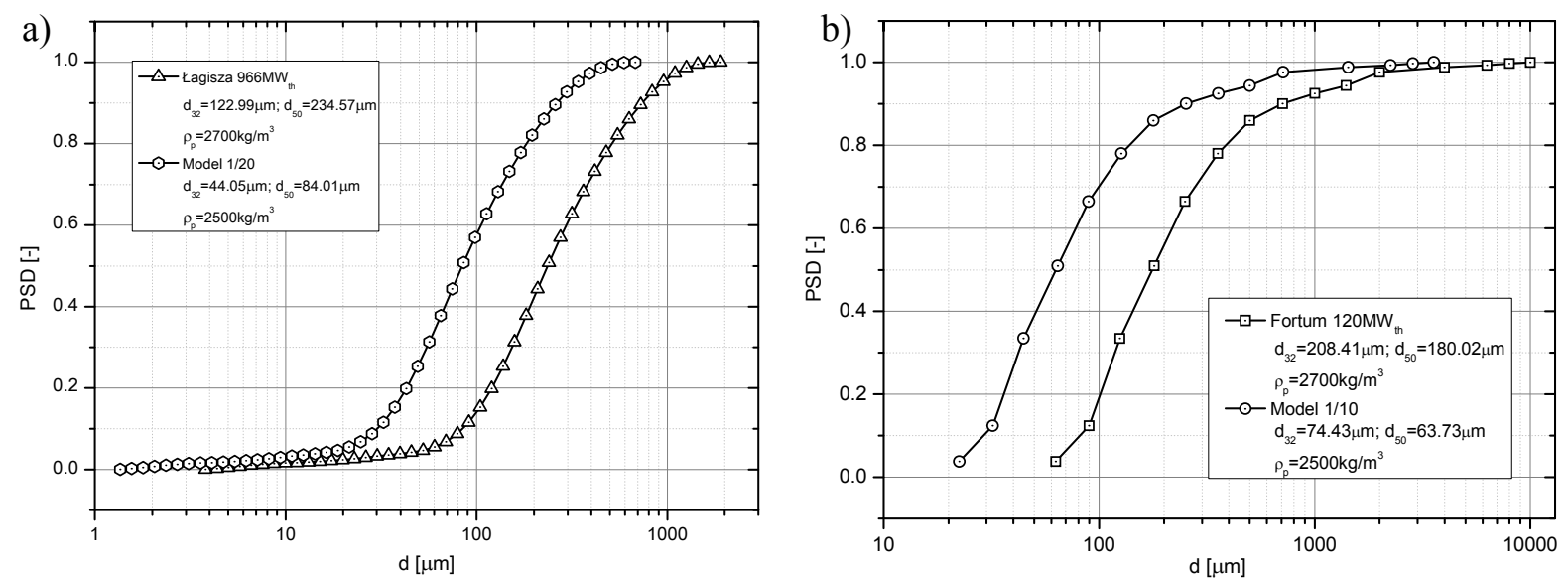

Fig. 3. PSDs of the granular material circulating in: a. Lagisza $966 \mathrm{MW}_{\text {th }}$ CFB boiler and the scaled-down model, b. Fortum $120 \mathrm{MW}_{\text {th }} \mathrm{CFB}$ boiler and the scaled-down model

In the case of the Lagisza $966 \mathrm{MW}_{\text {th }} \mathrm{CFB}$ boiler, the inert material was taken at the height of $8.3 \mathrm{~m}$ relative to the air distributor level, while in the Fortum $120 \mathrm{MW}_{\text {th }}$ CFB boiler, the material was taken directly from the combustion chamber air distributor. Experimental tests were carried out for two boiler loads, 100 and $40 \% \mathrm{MCR}$, with different velocities $U_{0}$ and different air flux ratios PA/SA corresponding to them. The values of these parameters are shown in Table 1.

\section{EXPERIMENTAL RESULTS}

During the experimental tests, the measurements of pressure gradients along the cold model working chamber height were taken, which were then converted into the value of the loose material suspension density, according to the relationship 


$$
\rho_{\text {sus }}=\frac{\partial p}{\partial L} \frac{1}{(1-\varepsilon) g}+\rho_{f}
$$

In view of the conditions of the cooperation agreement between the Czestochowa University of Technology and the AMEC Foster Wheeler company, Foster Wheeler Energia Polska Sp. z o.o., as well as the data protection provisions resulting from the Project FLEXI BURN CFB entitled: Development of High-Efficiency CFB Technology to Provide Flexible Air/Oxy Operation for a Power Plant with $C C S$, Grant Agreement number: 239188, the suspension density results were related to the maximum value and represented in a dimensionless form.

Figures 4 and 5 show the dimensionless distributions of loose material suspension density measured along the Lagisza $966 \mathrm{MW}_{\text {th }} \mathrm{CFB}$ boiler combustion chamber height and their corresponding distributions recorded on the cold model, for two mass loads: 100 and $40 \%$ MCR. The error bars in the plots represent more or less the greater of the standard deviation of a number of the solid suspension density measurements.

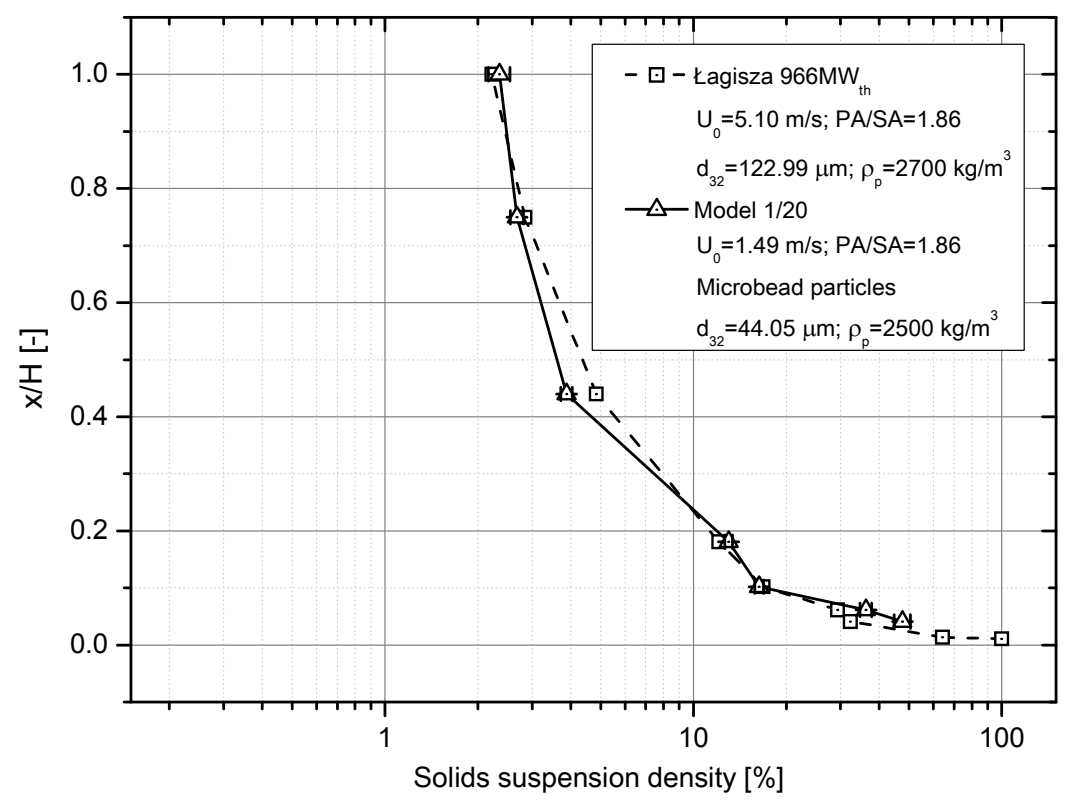

Fig. 4. Suspension density distributions for the Lagisza $966 \mathrm{MW}_{\text {th }}$ CFB boiler and the cold model 1/20 at $100 \% \mathrm{MCR}$

As can be noticed from Fig. 4, the suspension density distributions measured in the cold model are distinguished by a high degree of fitting with respect to the distributions recorded in the Lagisza 966 $\mathrm{MW}_{\text {th }} \mathrm{CFB}$ boiler. The greatest differences from the values measured in the boiler's combustion chamber were recorded for $x / H=0.44$ (ca. 25\%) and $x / H=0.04$ (ca. 48\%). In the dilute region $(x / H=0.44)$, the reason for the lower pressure gradient was the influence of the secondary air stream, which at the $100 \% \mathrm{MCR}$ had the highest value compared to the primary air stream $(\mathrm{PA} / \mathrm{SA}=1.86)$ and caused considerable dilution of the gas-solid mixture just above the supply region. In the dense zone $(0 \leq x / H<0.04)$, due to the very small distances between the static pressure taps p9 - p11 (see Fig. 2) located in the close vicinity of the grid it was impossible to achieve reasonable values of the solid suspension density. Therefore pressure measurements have been limited to only one point $(x / H=0.04)$. In distribution corresponding to the minimum boiler load, as represented in Fig. 5, the qualitative behaviour of variations in the inert material suspension density measured in the model stand was consistent with that recorded in the boiler. The values of this parameter determined from the model tests did not differ by more than thirty percent from those measured in the boiler combustion chamber. Similarly as for the maximum load, the largest differences relative to the laboratory measured values were noted in the dense region of the combustion chamber $(0 \leq x / H<0.04)$. In this part of the test-stand 
the difference between values measured in the boiler and the cold-model for $x / H=0.04$ was as high as $306 \%$. As in the case of maximum load this was the result of the too small distances between the static pressure taps which, located in the region of intensive loose material mixing, were exposed to the strong action of particles. Therefore, in scaling experiments carried out in small-scale cold models, a limiting factor can be the measurement of static pressure in the dense bed region, which should be performed with periodical blowing of the measurement ports.

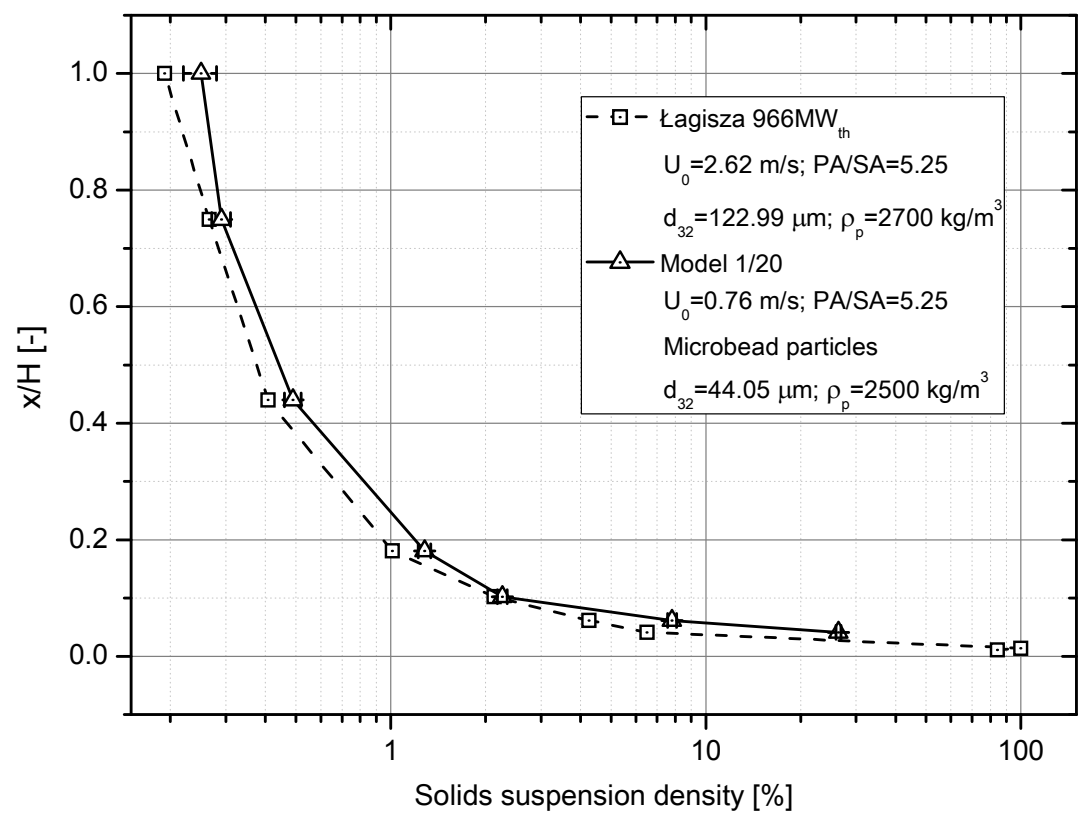

Fig. 5. Suspension density distributions for the Lagisza $966 \mathrm{MW}_{\text {th }} \mathrm{CFB}$ boiler and the cold model $1 / 20$ at $40 \% \mathrm{MCR}$

As follows from the comparison of the distributions shown in Figs. 4 and 5, with increasing mass load of the boiler combustion chamber, the suspension density distribution curve shifts towards higher values. This is associated with the gas velocity increasing with the boiler load, which increases the entrainment of the loose material along the combustion chamber height.

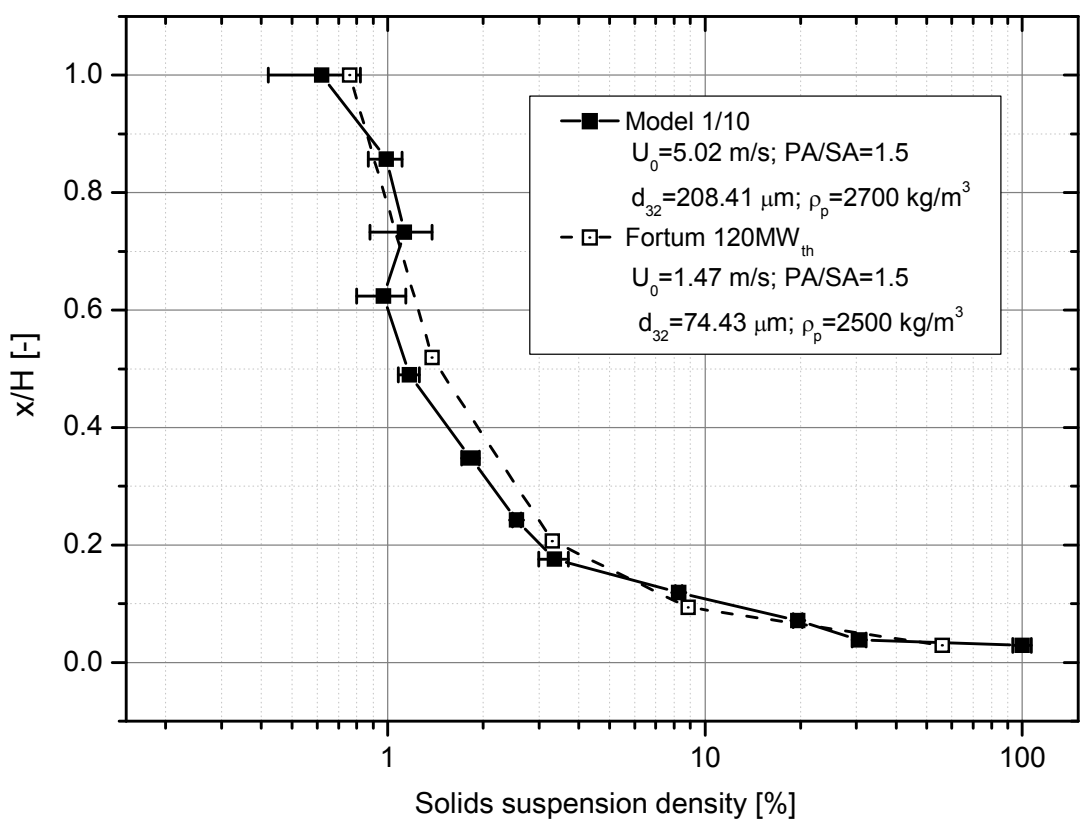

Fig. 6. Suspension density distributions for the Fortum $120 \mathrm{MW}_{\text {th }} \mathrm{CFB}$ boiler and the cold model 1/10 at $100 \% \mathrm{MCR}$ 


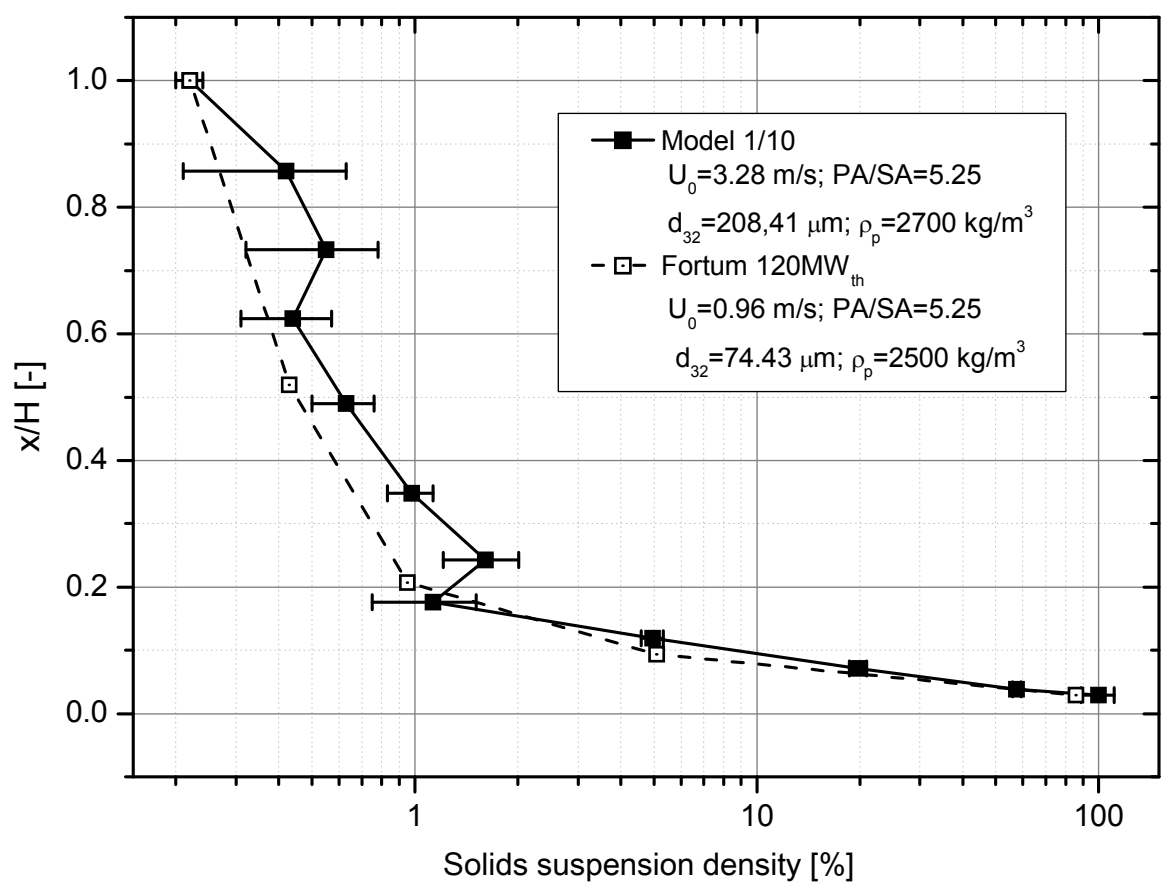

Fig. 7. Suspension density distributions for the Fortum $120 \mathrm{MW}_{\text {th }}$ CFB boiler and the cold model $1 / 10$ at $40 \% \mathrm{MCR}$

Figures 6 and 7 show the dimensionless distributions of the loose material suspension density measured along the Fortum $120 \mathrm{MW}_{\text {th }} \mathrm{CFB}$ boiler combustion chamber height and their corresponding distributions recorded in the cold model, for two mass loads: 100 and 40\% MCR, respectively.

As the presented characteristics show, in each of the tested loads, the qualitative suspension distribution is similar to the distribution obtained in real conditions, with the range of variations of the measured values being the larger, the greater the distance from the test stand air distributor is. This means that, in contrast to the Lagisza $966 \mathrm{MW}_{\text {th }} \mathrm{CFB}$ boiler, the scatter of values obtained in the lower region of the Fortum CFB boiler model is small. This is due to the larger scale of the test stand and thereby its lesser sensitivity to intensive mixing of particles in the near-grid region. Considering the suspension density values measured for two extreme mass loads of the stand, it can be found that, similarly as for the smaller-scale stand, the mass load increase causes the density distribution curve to shift towards greater values. It can also be noted that the scatter of measured values increases as the stand mass load decreases. This is the result of smaller mass flow of particles carried away in the cold model's working chamber and the accompanying larger pressure fluctuations caused by the reduction of gas velocity.

To sum up, it can be stated that the use of the simplified scaling laws enables the laboratory representation of the macroscopic flow pattern occurring in the CFB boiler combustion chamber, regardless of the combustion chamber design. A factor that limits scaling experiments is, however, the stand size, which plays a key role in modelling flows occurring in the dense region of a CFB boiler.

\section{CONCLUSIONS}

From our tests, the following conclusions can be drawn:

- The use of the simplified scaling laws makes it possible to represent the macroscopic flow pattern occurring in the CFB boiler combustion chamber in the cold model, regardless of the design of this model.

- In scaling experiments, the size of the cold model plays a crucial role. It is of particular importance in modelling flows occurring in the dense region of the combustion chamber of a 
CFB boiler. For the $1 / 10$-scale model of the Fortum $120 \mathrm{MW}_{\text {th }}$ CFB boiler, lloose material suspension density values in the near-grid region reached levels similar to those recorded in the actual boiler. For the Lagisza $966 \mathrm{MW}_{\text {th }}$ CFB boiler, due to the lsmall scale of the test stand, the measured suspension density values were biased with a gross error.

This investigation was financially supported by the FLEXI BURN CFB Project entitled: Development of High-Efficiency CFB Technology to Provide Flexible Air/Oxy Operation for a Power Plant with CCS, Grant Agreement number: 239188 and by the Czestochowa University of Technology scientific research fund number: $B S-P B-406-301 / 11$

\section{SYMBOLS}

Ar Archimedes number, $d_{p}{ }^{3} \rho_{f}\left(\rho_{p}-\rho_{f}\right) g / \mu^{2},-$

$C_{d} \quad$ drag coefficient, -

$d_{p} \quad$ particle diameter, $\mathrm{m}$

$d_{*} \quad$ dimensionless particle diameter, -

$d_{32} \quad$ Sauter mean particle diameter, $\mathrm{m}$

$d_{50} \quad$ mass mean particle diameter, $\mathrm{m}$

$D \quad$ riser hydraulic mean diameter, $\mathrm{m}$

$D_{h} \quad$ riser hydraulic mean diameter for model, $\mathrm{m}$

$D_{p} \quad$ riser hydraulic mean diameter for boiler, $\mathrm{m}$

$g \quad$ acceleration of gravity, $\mathrm{m} / \mathrm{s}^{2}$

$H \quad$ combustion chamber height, $\mathrm{m}$

$\dot{G}_{S} \quad$ external solids circulation flux, $\mathrm{kg} / \mathrm{m}^{2} \mathrm{~s}$

$L \quad$ riser height, $\mathrm{m}$

MCR Maximum Continuous Rating, \%

$U_{0} \quad$ superficial gas velocity, $\mathrm{m} / \mathrm{s}$

$u_{m f} \quad$ minimum fluidization velocity, $\mathrm{m} / \mathrm{s}$

$u_{t} \quad$ terminal velocity of particle, $\mathrm{m} / \mathrm{s}$

$p \quad$ pressure, $\mathrm{Pa}$

$P S D \quad$ particle size distribution

$P A / S A \quad$ primary/secondary air ratio, -

$R_{d} \quad$ particle Reynolds number, -

$T \quad$ temperature, $\mathrm{K}$

$x \quad$ coordinate of the combustion chamber height, $\mathrm{m}$

Greek symbols

$\rho_{\text {sus }} \quad$ solids suspension density, $\mathrm{kg} / \mathrm{m}^{3}$

$\rho_{b} \quad$ particle density in CFB boiler, $\mathrm{kg} / \mathrm{m}^{3}$

$\rho_{f} \quad$ gas density, $\mathrm{kg} / \mathrm{m}^{3}$

$\rho_{p} \quad$ particle density, $\mathrm{kg} / \mathrm{m}^{3}$

$\varphi \quad$ particle sphericity, -

$\mu \quad$ gas viscosity, $\mathrm{Pa} \mathrm{\textrm {s }}$

$\varepsilon \quad$ voidage, -

\section{Subscripts}

$b \quad$ CFB boiler

$m \quad$ cold model 


\section{REFERENCES}

Anderson T.B., Jackson R., 1967. A fluid mechanical description of fluidized beds. Equations of motion. Ind. Eng. Chem. Fundam., 6, 527-539. DOI: 10.1021/i160024a007.

Chang H., Louge M., 1992. Fluid dynamic similarity of circulating fluidized beds. Powder Technol., 70, $259-270$. DOI: $10.1016 / 0032-5910(92) 80061-Z$.

Glicksman L.R., 2003. Fluidized Bed Scaleup, In: Yang W.-Ch. (Ed.), Handbook of fluidization and fluid-particle systems. Marcel Dekker, Inc., New York.

Glicksman L.R., Hyre M.R., Westphalen D., 1993. Verification of scaling relations for circulating fluidized beds. Proceedings of the 12th International Conference on Fluidized Bed Combustion, 1993, 69-80.

Glicksman L.R., Hyre M., Woloshun K., 1993. Simplified scaling relationships for fluidized beds. Powder Technol., 77, 177-199. DOI: 10.1016/0032-5910(93)80055-F.

Glicksman L.R., Westphalen D., Brereton C., Grace J.R., 1990. Verification of the scaling laws for circulating fluidized beds. Proceedings of the third international conference on circulating fluidized beds, 1990, Nagoya, Japan, 119-124.

Glicksman L.R., Yule T., Dyrness A., Carson R., 1987. Scaling the hydrodynamics of fluidized bed combustors with cold models: experimental confirmation. Proceedings of the 9th International Conference on Fluidized Bed Combustors, 511-514.

Grace J.R., Knowlton T.M., Avidan A.A., 1996. Circulating Fluidized Beds. Blackie Academic and Professional, 65-74.

Horio M., 1997. Hydrodynamics, In: Grace J.R., Avidan A.A., Knowlton T.M. (Eds.), Circulating fluidized beds. Blackie Academic and Professional, London.

Horio M., Ishii H., Kobukai Y., Yamanishi N., 1989. A scaling law for circulating fluidized beds. J. Chem. Eng. Japan, 22(6), 587-592. DOI: 10.1252/jcej.22.587.

Kolar A.K., Leckner B., 2006. Scaling of CFB boiler hydrodynamics. Proceedings of the 1st National Conference on Advances in Energy Research (AER 2006). Mumbai, 34-40.

Mirek P., 2011. Scaling of the flow phenomena in Circulating Fluidized Bed boilers. Chem. Process Eng., 32, 91-100. DOI: 10.2478/v10176-011-0008-4.

Mirek P., 2011. A simplified methodology for scaling hydrodynamic data from Lagisza 460MWe supercritical CFB boiler. Chem. Process Eng., 32, 245-253. DOI: 10.2478/v10176-011-0019-1.

Mirek P., Ziaja J., Klajny M., Nowak W., Jagodzik Sz., 2014. Experimental verification of the scaling rules for cold models of different scales. Proceedings of the 11th International Conference on Fluidized Bed Technology. Bejing, China, 14-17 May 2014, 499-504.

Van der Meer E. H., Thorpe R. B., Davidson J. F., 1999. Dimensionless groups for practicable similarity of circulating fluidized beds. Chem. Eng. Sci., 54, 5369-5376. DOI: 10.1016/S0009-2509(99)00270-5.

Werther J., Hartge E.U., 2014. Bridges between industrial practice and fundamental research in fluidization technology. Proceedings of the 11th International Conference on Fluidized Bed Technology. Bejing, China, 14-17 May 2014, 1-21. 